$1-1-2000$

\title{
Infrastructure and economic development : what is their relationship in West Virginia?
}

Kristen Sagath Corwin

Alan R. Collins

Follow this and additional works at: https://researchrepository.wvu.edu/ wv_agricultural_and_forestry_experiment_station_bulletins

\section{Digital Commons Citation}

Corwin, Kristen Sagath and Collins, Alan R., "Infrastructure and economic development : what is their relationship in West Virginia?" (2000). West Virginia Agricultural and Forestry Experiment Station Bulletins. 719.

https://researchrepository.wvu.edu/wv_agricultural_and_forestry_experiment_station_bulletins/610 @ WVU. It has been accepted for inclusion in West Virginia Agricultural and Forestry Experiment Station Bulletins by an authorized administrator of The Research Repository @ WVU. For more information, please contact ian.harmon@mail.wvu.edu. 


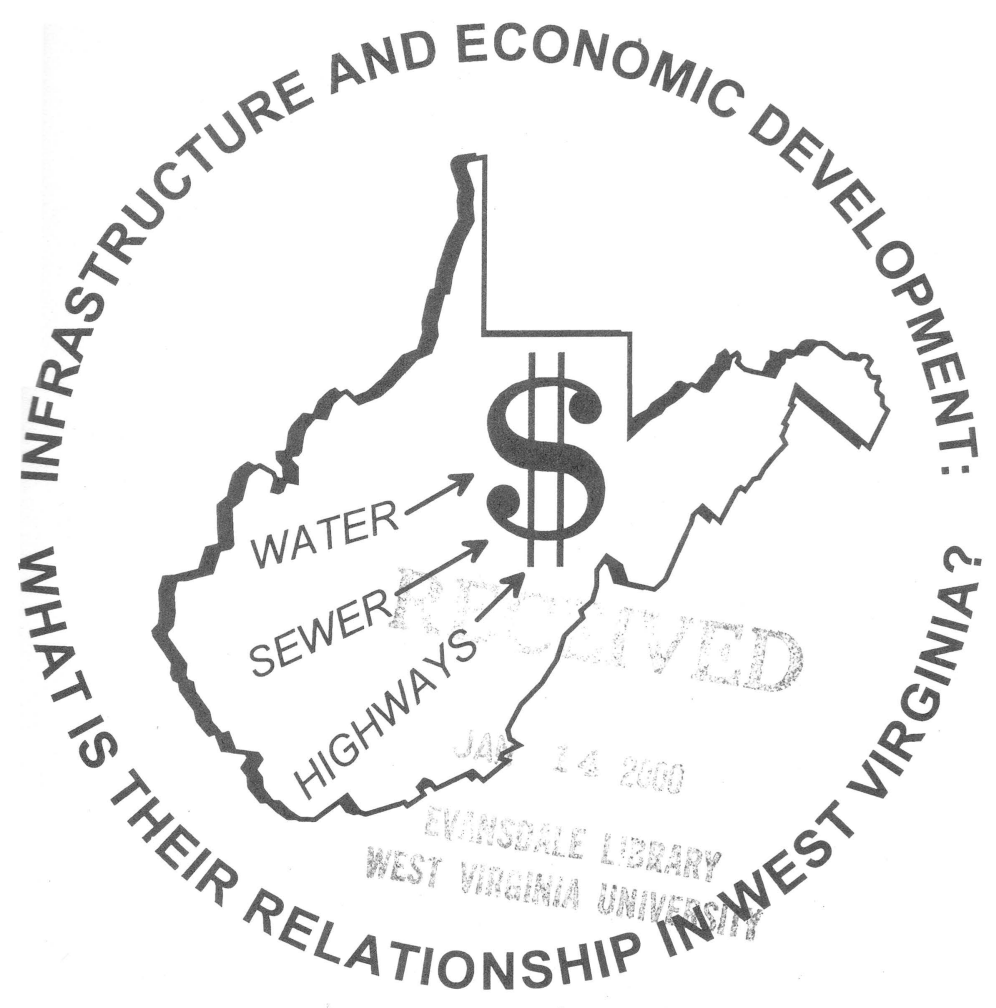

By

Kristen Sagath Corwin and Alan R. Collins

\author{
Bulletin 719 \\ West Virginia Agricultural \\ and Forestry Experiment Station \\ West VirginiaUniversity
}


Kristen Sagath Corwin is a former graduate research assistant in the West Virginia University College of Agriculture, Forestry, and Consumer Sciences Division of Resource Management. Alan R. Collins is an associate professor in the Division. This research was supported with funds appropriated under the Hatch Act and with the support of the West Virginia University Research Corporation.

\author{
West Virginia University \\ West Virginia Agricultural and Forestry Experiment Station \\ College of Agriculture, Forestry and Consumer Sciences \\ Robert Dailey, Interim Dean and Director \\ 1170 Agricultural Sciences Building \\ PO Box 6108 \\ Morgantown, WV 26506-6108 \\ Visit our Web Site at http://www.caf.wvu.edu/
}




\title{
ECONOMIC DEVELOPMENT AND INFRASTRUCTURE: WHAT IS THEIR RELATIONSHIP IN WEST VIRGINIA?
}

\author{
BY KRISTEN SAGATH CORWIN \\ AND ALAN R. COLLINS
}

TABLE OF CONTENTS

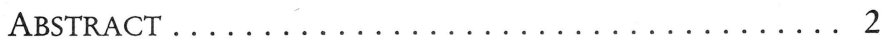

INTRODUCTION $\ldots \ldots \ldots \ldots \ldots \ldots \ldots \ldots \ldots \ldots$

LITERATURE REVIEW $\ldots \ldots \ldots \ldots \ldots \ldots \ldots \ldots$

ECONOMIC MODEL ................. 10

DATA AND METHODS $\ldots \ldots \ldots \ldots \ldots \ldots \ldots \ldots \ldots$

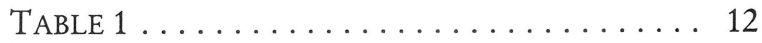

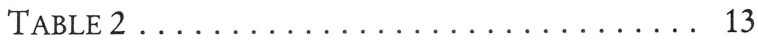

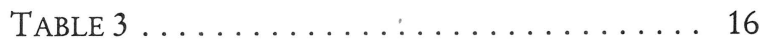

RESUlTS ....................... 17

TABLE $4 \ldots \ldots \ldots \ldots \ldots \ldots \ldots \ldots \ldots$

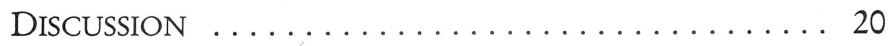

REFERENCES ...................... 26

APPENDIX ....................... 30 


\begin{abstract}
The purpose of this study was to determine what type of relationship exists between economic development and infrastructure investment. County level data between 1980 and 1994 for all 55 West Virginia counties were used to estimate this relationship. Water and sewer infrastructure variables served as explanatory variables for gross domestic product (GDP) growth. These infrastructure variables either had a zero or negative impact on GDP growth. The highway infrastructure variable, however, had a positive impact on employment. Research results show that a onemile expansion of highway mileage increases the demand for county level employment by between 120 and 70 jobs. This positive impact on employment was short lived -- lasting less than 10 years. This analysis of historical data from West Virginia indicated that investments in water and sewer infrastructure alone were not sufficient to promote county economic development. Water and sewer infrastructure, however, still should be part of an integrated economic development strategy to attract and retain business and other institutions which generate economic activity.
\end{abstract}




\section{INTRODUCTION}

The purpose of this study was to determine the extent of the relationship that exists between economic development and infrastructure investment. Infrastructure was defined as the physical components of public capital (water, sewer, and highway) and economic development is defined as the amount of employment and economic activity within a county region. Knowledge about this relationship is important because local governments in rural areas face continual pressures to implement infrastructure investment policies in order to stimulate employment and economic activity. Thus, the question is to what extent will infrastructure provide a stimulus to employment and/or economic activity within a county or region?

Infrastructure is one of many factors that affect economic development in rural areas. For example, Dilger and Witt (1994) identified fifteen key factors related to growth economic growth in West Virginia. These factors included labor quality, labor/management relations, access to present and new markets, government and business climate, financing programs, business incentives, access to supply sources, and the capacity of technology transfer. The authors compared West Virginia's economic competitiveness to the economies of 11 other surrounding or southeastern states and found that West Virginia ranked last.
A lack of suitable land sites was identified as a key factor to West Virginia's low economic competitiveness. A suitable site was defined to be level land where construction is possible without extensive grading, all the necessary utilities (water, sewer, electricity, etc.) are available, and access to roads exists (Dilger and Witt 1994). Therefore, a major issue for local governments is whether to devote scarce capital resources to develop the necessary water, sewer, and road infrastructure to create such sites. 
The focus of infrastructure investment in West Virginia has been on highways. Highway infrastructure has improved dramatically over the previous three decades beginning with the passage of the Appalachian Regional Development Act of 1965 (WV Division of Highways 1992). This Act created provisions for construction of an Appalachia Development Highway System. Its purpose was to stimulate economic growth and development by enhancing access and mobility. Under this act, over $\$ 1.4$ billion has been spent on road construction in West Virginia (Appalachian Regional Commission 1997).

In contrast to highway infrastructure improvements, West Virginia is still lacking adequate water and sewer infrastructures in many rural areas. The Council for Community and Economic Development (1994) concluded that more than $\$ 90$ million was needed immediately for water and sewer infrastructure improvement and site development. In 1990, the Division of Natural Resources estimated that it would cost more than $\$ 2$ billion to bring all of West Virginia's publicly owned wastewater treatment facilities into compliance with the federal government's water quality standards.

Prior to 1994, the state of West Virginia did not have its own grant and loan program to help upgrade wastewater treatment plants and water delivery systems around the state. To rectify this situation, the state legislature passed the West Virginia Infrastructure and Job Development Act during the 1994 session. This legislation set aside the first $\$ 16$ million collected annually from severance taxes (primarily from coal extraction) to finance a pay-as-you-go financial structure for investments in infrastructure. Eighty percent was designated for water and sewer projects and 20 percent for site development. The West Virginia legislature also adopted the Infrastructure Improvement Amendment, which permitted $\$ 300$ million of bond debt to be issued 
towards investment upon approval of a statewide referendum, which occurred in November of 1994.

This study was undertaken in response to voter approval of $\$ 300$ million in bonds for water and sewer infrastructure funding. Referendum proponents claimed that the investments in water and sewer infrastructure created by these bonds would stimulate economic development around the state (Seiler 1994). Numerous researchers have examined how infrastructure, in particular water and sewer, impacts the economy of the surrounding areas. Rephann and Isserman (1994), Fox and Smith (1990), Munnell (1990) and Duffy-Deno and Eberts (1989) found that public infrastructure had positive impacts on economic development. Conrad and Seitz (1994) and Munnell (1990) also concluded that infrastructure positively impacted productivity in the economy. Moomaw, Mullen, and Williams (1995) came to the conclusion that increased spending on public infrastructure - particularly water and sewer systems - increases regional economic activity. Water and sewer systems were found to have a much greater effect on state output than highways and other public capital stocks.

In contrast to the above research, Cox, Grover, and Siskin (1971) and Howe (1968) argued that infrastructure is not likely to stimulate economic growth. Boarnet (1997), HoltzEakin (1994) and Hulten and Schwab (1991) found that infrastructure did not affect economic productivity. Kelejian and Robinson (1997) found that infrastructure negatively affected economic productivity.

Given these contradictory results, what is the impact of water, sewer, and highway infrastructure on local economies in West Virginia? To address this question, this study had two objectives: 
1. The primary objective of this study was to examine the relationship between water, sewer, and highway infrastructure investment and economic development for the counties of West Virginia.

2. The secondary objective was to explore the impact of federal and state funding (both loan and grant programs) of water and sewer infrastructure on economic development in West Virginia.

The next section provides a literature review on the impact of infrastructure on economic development with a focus on water and sewer infrastructure. The economic model section introduces the simultaneous system of equations in which infrastructure investment is related to employment supply and economic activity. A data and methods section explains the infrastructure data collected and estimation techniques. Finally, in the results and conclusions sections, coefficient estimations are presented which show that water and sewer infrastructure investments were found to have negative impacts on county level economic activity. Highway infrastructure, however, had a positive, although relatively short-term effect on employment supply. Four possible explanations are provided for the negative impacts from water and sewer infrastructure investments.

\section{LITERATURE REVIEW}

The economic impacts of infrastructure include economic development; economic output or productivity; and the combined effects on the economy and productivity. The research literature will be discussed in this order.

Duffy-Deno and Eberts (1989) examined the effects of infrastructure on regional economic development using a simultaneous system of equations. This model related per capita personal income to energy price, unemployment, 
population, private capital and public infrastructure (both capital stock and investment). They found that both public capital stock and investment had positive and statistically significant effects on per capita personal income. The impacts of public capital stock were postulated to occur via employment increases at the construction phase, public capital stock as an unpaid factor in private production processes, and public capital stock as consumption good. They noted that the importance of public capital for regional growth stems from its effect on the production and location decisions of private industry. Therefore, "well maintained public infrastructure should be an important component of any policy package designed to promote regional economic development" (Duffy-Deno and Eberts 1989, 20).

Fox and Smith (1990) focused on highway, water, and sewer infrastructure investments. While water and sewer infrastructure supported economic activity, they found no evidence that building new infrastructure (alone) caused a region to undergo positive economic development. "Infrastructure cannot be expected to stimulate the economies of all communities, but most communities can benefit from exploring new ways to deliver infrastructure services" (Fox and Smith 1990, 49).

Fox and Smith viewed economic development possibilities through three regions: intermediate, congested, and lagged. Intermediate was most likely to benefit from infrastructure with increased economic development as most factors needed for development are already in place. In the congested region, the benefits must outweigh the additional costs, which are caused by increases in population and congestion that increases some of the region's costs. Lagged regions were typically unable to maintain the infrastructure already in place. Infrastructure investment was less likely to boost economic development in lagging regions than in 
intermediate or congested regions because lagging regions lack other characteristics necessary to attract new economic activity. "Linkage between infrastructure and economic development clearly depends on the individual location in question" (Fox, Smith 1990, 55).

Rephann and Isserman (1994) studied the effect new highways can have on economic development. They utilized quasi-experimental matching methods that compared "twincounties": one with and one without a new highway. They found that the urban spillover regions gain competitive advantages from highway links and experience positive economic effects on tertiary industry (Rephann and Isserman 1994). In noncompetitive regions, new highway projects had little effect on total income or earnings. They concluded that highways were necessary but not sufficient for economic growth and development.

Conrad and Seitz (1994) examined the connection between public infrastructure and the productivity of private business. By using a dual cost function, they found that investing in infrastructure boosts economic growth by increasing productivity, which is a complement to private investment. They concluded that infrastructure capital is labor saving but capital using and that it enhances the total factor productivity. Holtz-Eakin (1994) utilized regression analysis and instrumental variables to relate output to public capital. Positive impacts were found for state level output, but no statistically significant impacts were found at a regional level. Kelejian and Robinson (1997) used a production function with multiple variations to account for spatial effects to relate private output with public capital. They found a negative relationship existed between output and public capital.

Moomaw et al. (1995) examined the link between declining regional competitiveness and the deterioration of physical 
infrastructure, such as highways, bridges, water and sewer systems, and "other" public infrastructure. They estimated a production function with labor, private capital, and public capital as separate inputs. State level data on economic input from 1970, 1980, and 1986 were separated into the following regions: northeast, north central, south, and west. They found that water and sewer infrastructure had the greatest impact on gross state product in southern and western states. They concluded that increased spending on public infrastructure - particularly water and sewer systems - would enhance regional economic activity. Water and sewer systems had a much greater effect on state output than highways and "other" public capital stocks. State-specific characteristics were important in explaining the role of infrastructure investment in economic development (Moomaw et al. 1995).

Munnell (1990) examined the impact of public capital on both employment growth and productivity. She found that public capital had a positive impact on both state-level productivity and employment. Munnell attributed the positive impact of infrastructure to the observation that high-quality infrastructure, such as roads and sewer systems, encourages firms and people to move to areas where it exists. Both Moomaw et al. (1995) and Munnell (1990) computed the output elasticity of public capital. Munnell found that the elasticity for private capital was two times as large as that of public capital. Moomaw et al. noted that the water and sewer systems created economic output at approximately twice the rate of highways.

Hulten and Schwab (1991) addressed the impacts of infrastructure on productivity in the manufacturing industry. An estimated model was used to determine the direct effect of a Hicks neutral shift in production function, combined with the indirect impacts of infrastructure on output. They found few differences in productivity across 
regions in the U.S. and concluded that the existence of infrastructure differences across regions did not seem to be a major determinant of productivity differences.

\section{ECONOMIC MODEL}

Based upon existing research, a positive relationship exists between economic development and infrastructure investment. To test a hypothesized positive relationship between economic development and water, sewer, and highway infrastructure, the following simultaneous system of equations was examined:

$$
\begin{gathered}
\text { Employment supply }=\mathrm{f} \begin{array}{c}
\text { (population, } \\
\text { wage rate) }
\end{array} \\
\text { Employment demand }=\mathrm{f} \\
\begin{array}{c}
\text { (economic } \\
\text { activity, } \\
\text { wage rate, } \\
\text { infrastructure } \\
\text { availability) }
\end{array} \\
\text { Economic activity = } \mathrm{f} \text { (private capital, } \\
\text { population, } \\
\text { infrastructure } \\
\text { investment) }
\end{gathered}
$$

In this model, employment demand and economic activity were related to infrastructure. In (3), economic activity (county level GDP) was explained in a production function relationship by using capital (private and public) and labor (population). Infrastructure investments (highways, water, and sewer) were hypothesized to affect the economic activity of a county through their ability to attract businesses to the area and to enhance the productivity of existing businesses. Positive relationships were expected for each of these explanatory factors in (3). 
The demand for employment in (2) was explained by the factors of economic activity, wages, and infrastructure availability. A positive relationship was expected between the demand for employment and the level of economic activity in a county, while a negative relationship was expected between demand and wage rates. Increased infrastructure availability was expected to have a positive impact on demand due to attraction of new businesses into a county. Employment supply in (1) was related to population and wage rates. Both factors were expected to have positive impacts on the supply of labor.

\section{DATA AND METHODS}

Infrastructure data on water and sewer were collected from various federal and state agencies (Table 1). These data were based on loans and grants given to public service districts and municipalities in West Virginia for water and/or sewer projects between 1964 and 1994. The loans and grants varied in monetary value from $\$ 100$ to $\$ 22.6$ million. Highway infrastructure was measured in miles and defined as two- or four-lane, non-local, interstate roadways (Lewis 1998).

Water and sewer infrastructure data were aggregated to the county level to be comparable to other economic data. The loan and grant dollar amounts were then indexed in accordance with 1992 as the base year, using the Producer Price Index. The data for each county were summed and placed into the following categories: water and sewer loans, water and sewer grants, water loans and grants, sewer loans and grants, and water and sewer loans and grants.

Definitions of the variables employed in this study are provided in Table 2. Equation (1) used population (POP) and the wage rate (WAGE) to explain the supply of employment (EMPLOY) for the counties of West Virginia. Equation (2) explained the demand of employment 
(EMPLOY) by county level economic activity (GDP), the wage rate (WAGE), and infrastructure availability (SWLG, W, S, L, or G and HWY). Equation (3) related economic activity (GDP) to private capital (VALUE), population (POP), and infrastructure availability (SWLG, W, S, L, or G and HWY).

Table 1. Sources of Financial Assistance for Infrastructure Development.

\begin{tabular}{llc}
\hline \multicolumn{1}{c}{ Agency } & \multicolumn{1}{c}{ Type of Assistance } & Years \\
\hline $\begin{array}{l}\text { West Virginia Water } \\
\text { Development Authority }\end{array}$ & $\begin{array}{l}\text { Water and Sewer Loans } \\
\text { and Grants }\end{array}$ & 1974 to 1994 \\
\hline $\begin{array}{l}\text { Department of } \\
\text { Environmental } \\
\text { Protection }\end{array}$ & Sewer Loans & 1991 to 1994 \\
\hline $\begin{array}{l}\text { The West Virginia } \\
\text { Development Office }\end{array}$ & Water and Sewer Grants & 1972 to 1994 \\
\hline $\begin{array}{l}\text { The Environmental } \\
\text { Protection Agency }\end{array}$ & Sewer Grants & 1972 to 1994 \\
\hline $\begin{array}{l}\text { USDA Rural Utilities } \\
\text { Services }\end{array}$ & $\begin{array}{l}\text { Water and Sewer Loans } \\
\text { and Grants }\end{array}$ & 1964 to 1994 \\
\hline
\end{tabular}


Table 2. Variables Created in This Study.

\begin{tabular}{|c|c|c|}
\hline Variable & Definition & Source \\
\hline $\begin{array}{l}\text { Employment } \\
\text { (EMPLOY) }\end{array}$ & $\begin{array}{l}\text { Average annual } \\
\text { employment of WV } \\
\text { counties (thousands of } \\
\text { jobs) }\end{array}$ & $\begin{array}{l}\text { West Virginia } \\
\text { Statistical Abstract: } \\
\text { 1995-1996 }\end{array}$ \\
\hline $\begin{array}{l}\text { Highways } \\
\text { (HWY) }\end{array}$ & $\begin{array}{l}\text { Two- to four-lane, non- } \\
\text { local, interstate roadways } \\
\text { (miles) }\end{array}$ & Lewis (1998) \\
\hline $\begin{array}{l}\text { County Gross } \\
\text { Domestic } \\
\text { Product (GDP) }\end{array}$ & $\begin{array}{l}\text { GDP = employee } \\
\text { compensation }+ \\
\text { proprietors' income } \\
\text { (capital charges }+ \\
\text { indirect business taxes) } \\
\text { (millions of dollars) }\end{array}$ & $\begin{array}{l}\text { West Virginia } \\
\text { Statistical Abstract: } \\
\text { 1995-1996 }\end{array}$ \\
\hline Population (POP) & $\begin{array}{l}\text { Annual population of } \\
\text { WV counties (thousands) }\end{array}$ & $\begin{array}{l}\text { West Virginia } \\
\text { Statistical Abstract: } \\
\text { 1995-1996 }\end{array}$ \\
\hline Value (VALUE) & $\begin{array}{l}\text { Total assessed valuation } \\
\text { of all property in WV } \\
\text { counties (millions of } \\
\text { dollars) }\end{array}$ & $\begin{array}{l}\text { Bureau of Economic } \\
\text { Analysis, Childs } \\
\text { (1998) }\end{array}$ \\
\hline Wage (WAGE) & $\begin{array}{l}\text { Average annual wage of } \\
\text { WV counties (thousands) }\end{array}$ & $\begin{array}{l}\text { West Virginia } \\
\text { Statistical Abstract: } \\
\text { 1995-1996 }\end{array}$ \\
\hline $\begin{array}{l}\text { Sewer and Water } \\
\text { Loans and Grants } \\
\text { (SWLG) }\end{array}$ & $\begin{array}{l}\text { Sewer and water loans } \\
\text { and grants for } \\
\text { municipalities and Public } \\
\text { Service Districts of WV } \\
\text { counties between } 1964 \\
\text { and } 1994 \text { (measured in } \\
\text { thousands of dollars per } \\
\text { capita) }\end{array}$ & $\begin{array}{l}\text { Five federal and state } \\
\text { agencies (refer to } \\
\text { Table 1) }\end{array}$ \\
\hline
\end{tabular}




\begin{tabular}{lll}
\hline $\begin{array}{l}\text { Sewer Loans and } \\
\text { Grants (S) }\end{array}$ & $\begin{array}{l}\text { Sewer loans and grants } \\
\text { for municipalities and } \\
\text { Public Service Districts } \\
\text { of WV counties between } \\
1964 \text { and 1994 }\end{array}$ & $\begin{array}{l}\text { Five federal and state } \\
\text { agencies (refer to } \\
\text { Table 1) }\end{array}$ \\
\hline $\begin{array}{lll}\text { Water Loans and } \\
\text { Grants (W) }\end{array}$ & $\begin{array}{l}\text { Water loans and grants } \\
\text { for municipalities and } \\
\text { Public Service Districts } \\
\text { of WV counties between } \\
\text { 1964 and 1994 }\end{array}$ & $\begin{array}{l}\text { Five federal and state } \\
\text { agencies (refer to }\end{array}$ \\
\hline $\begin{array}{l}\text { Table 1) } \\
\text { Loans (L) }\end{array}$ & $\begin{array}{l}\text { Water and sewer loans } \\
\text { for municipalities and } \\
\text { Public Service Districts } \\
\text { of WV counties between } \\
\text { 1964 and 1994 }\end{array}$ & $\begin{array}{l}\text { Five federal and state } \\
\text { agencies (refer to }\end{array}$ \\
\hline Table 1) \\
\hline $\begin{array}{l}\text { Water and Sewer } \\
\text { Grants (G) }\end{array}$ & $\begin{array}{l}\text { for municipalities and } \\
\text { Public Service Districts } \\
\text { of WV counties between } \\
\text { 1964 and 1994 }\end{array}$ & $\begin{array}{l}\text { Five federal and state } \\
\text { agencies (refer to }\end{array}$ \\
\hline
\end{tabular}

${ }^{1}$ All of the water and sewer infrastructure data were measured in thousands of dollars per capita.

One issue that arose during the collection of the data was whether the federal and state agencies listed in Table 1 provided more loans and grants to rural, low-income counties than to wealthier, more urban counties. Such a distribution could potentially bias our analysis by being responsible for a negative rather than positive relationship between economic development and infrastructure in the estimation. Two analyses were conducted to address this issue: (1) West Virginia counties were separated into metropolitan (10 counties) and non-metropolitan (45 counties); and (2) West Virginia counties were divided into three categories (top, middle, and bottom) based upon per capita GDP. Averages were computed for per capita water and sewer loans and grants at four time periods: 1980, 1985, 1990, and 1994. Per capita averages for the four time periods 
were almost identical between metropolitan and nonmetropolitan counties (Table 3). Some differences in per capita sewer and water loans and grants existed when counties were ranked by per capita GDP, especially in 1985 . These differences were not large nor were they consistently biased towards lower per capita GDP counties. These results provided assurance about no distribution bias existing among per capita measures of water and sewer loans and grants data.

Equations (1), (2), and (3) represent an over-identified system of equations based upon conditions for identification discussed in Judge et. al. (1982). To rectify this problem, weighted, two-stage least squares (WTSLS) regression was employed with the weights of the variables equal to one (Gujarati 1995). Instrumental variables included in WTSLS were POP, VALUE, HWY, and the sewer and water infrastructure variables. These variables had the highest correlation coefficients with the dependent variables, yet were not closely correlated with the error term.

Initially, coefficients were estimated with WTSLS one system of equations for each time period. However, because the data (particularly infrastructure) were related over time, it was decided that stacking the data would be more effective. Stacked data allow time series analysis to be combined with cross-sectional analysis into one regression analysis. Data were stacked by alphabetical order for the 55 counties of West Virginia and over four time periods: 1980, 1985,1990 , and 1994. Dummy variables were used in the stacking procedure to separate the data by time period. 
Table 3. Impacts of Metropolitan vs. Non-Metropolitan and GDP Rank on Infrastructure Distribution of Loans and Grants.

\begin{tabular}{lcccc}
\hline & \multicolumn{4}{c}{ Per Capita Sewer and Water Loans and Grants } \\
\hline & 1980 & 1985 & 1990 & 1994 \\
\hline Metropolitan & 0.07 & 0.13 & 0.24 & 0.32 \\
Non-Metropolitan & 0.05 & 0.13 & 0.24 & 0.35 \\
\hline GDP Rank & & & & \\
\hline Top 1/3 & 0.06 & 0.10 & 0.25 & 0.32 \\
Middle 1/3 & 0.05 & 0.15 & 0.24 & 0.34 \\
Low 1/3 & 0.05 & 0.16 & 0.24 & 0.37 \\
\hline
\end{tabular}

Three models were estimated with stacked data. Model A included the water and sewer loans and grants as a single variable (SWLG). In Model B, infrastructure was separated into water loans and grants (W) and sewer loans and grants (S). Infrastructure were categorized by financing in Model C: loans $(\mathrm{L})$ and grants $(\mathrm{G})$. The stacked models were estimated as:

Employment Supply Equation ${ }^{2}$ :

$$
\begin{aligned}
& \text { EMPLOY*D_xx }= \\
& \beta_{1}+\beta_{2} * \text { POP*D_xx }+ \\
& \beta_{3} * \text { WAGE } * D \_x x+\varepsilon_{1}
\end{aligned}
$$

Employment Demand Equation:

$$
\begin{aligned}
& \text { EMPLOY*D_xx }= \\
& \beta_{4}+\beta_{5} * G D P * D_{-} \mathrm{xx}+ \\
& \beta_{6} * \text { WAGE } \mathrm{DA}_{-} \mathrm{xx}+ \\
& \beta_{7} * \mathrm{HWY} * \mathrm{D}_{-} \mathrm{xx}+\varepsilon_{2}
\end{aligned}
$$


GDP Equation:

$$
\begin{aligned}
& \text { GDP }: D x x= \\
& \beta_{8}+\beta_{9}{ }^{*} \text { VALUE*D_xx }+ \\
& \beta_{10} \text { "POP*D_xx }+ \\
& \beta_{11}{ }^{*} \mathrm{HWY}{ }^{*} \bar{D}_{-} \mathrm{xx}+\mathrm{A}, \mathrm{B} \text {, or } \mathrm{C}+\varepsilon_{3} \\
& \mathrm{~A}=\beta_{12} *(\mathrm{SWLG}) * \mathrm{D}_{-} \mathrm{xx} \\
& \mathrm{B}=\beta_{13} * \mathrm{~W} * \mathrm{D}_{-} \mathrm{xx}+\bar{\beta}_{14} * \mathrm{~S} * \mathrm{D}_{-} \mathrm{xx} \\
& C=\beta_{15} * L^{*} D_{-} x x+\beta_{16} * G^{*} D_{-} x x
\end{aligned}
$$

${ }^{2}$ D_xx represents a dummy variable for the xx period (1980, 1985 , 1990, or 1994). $\varepsilon_{1}, \varepsilon_{2}$, and $\varepsilon_{3}$ represent error terms.

\section{RESULTS}

The coefficients estimated by WTSLS had similar coefficient signs over the four time periods (1980,1985, 1990, and 1994) and across models utilizing different infrastructure variables. A summary of the coefficient signs and statistical significance is presented in Table 4. The estimated coefficients from WTSLS are presented in Appendix A.

As expected, the POP and VALUE variables had positive, statistically significant coefficients in explaining GDP. Similarly, GDP had positive, statistically significant coefficients in equation (2). The HWY infrastructure variable had a positive, statistically significant coefficient in two time periods (1980 and 1994) for employment demand. The 1985 and 1990 coefficient estimates were not statistically different from zero, showing no impact on employment from highways. The HWY variable had a zero impact on GDP during all four time periods. 
Table 4. Summary of Results from WTSLS Regression Analyses.

\begin{tabular}{ccc}
\hline Variable & $\begin{array}{c}\text { Sign of } \\
\text { Estimated } \\
\text { Coefficient }\end{array}$ & $\begin{array}{c}\text { Estimations where Statistical } \\
\text { Significance was found in } \\
\text { Equations (1), (2), and (3) }\end{array}$ \\
\hline POP & $(+)$ & $\begin{array}{c}\text { All four time periods Equation (1) } \\
\text { and 1980 and 1990 for Equation (3) }\end{array}$ \\
GDP & $(+)$ & All four time periods Equation (2) \\
VALUE & $(+)$ & 1980, 1985, and 1990 Equation (3) \\
HWY & $(+)$ & 1980 and 1994 Equation (2) \\
WAGE & $(-)$ & $\begin{array}{c}\text { All four time periods Equation (1) } \\
\text { and 1994 Equation (2) }\end{array}$ \\
SWLG & $(-)$ & $1980,1990,1994$ Equation (3) \\
W & $(-)$ & 1994 Equation (3) \\
S & $(-)$ & 1990 and 1994 Equation (3) \\
L & $(-)$ & 1980,1990, and 1994 Equation (3) \\
G & $(-)$ & 1980 Equation (3)
\end{tabular}

Contrary to prior expectations, wage rate had statistically significant, negative coefficients explaining the supply of labor in equation (1). Thus, higher wages reduced the supply of labor. This finding may be attributed to several factors unique to West Virginia: (a) the particularly low labor force participation rate of females in West Virginia (Rogers, Mencken, and Mencken 1997) so that higher average wage rates in a county may lead to more single, wage earner families; or (b) a high-wage, high-unemployment phenomena existing in counties dominated by mining and manufacturing industries so that unemployed individuals wait for high wages jobs rather than re-locate (Weiler 1997). 
Water and sewer infrastructure variables also had coefficient estimates that were contrary to prior expectations - either statistically insignificant coefficient estimates (zero impact) or negative, statistically significant coefficients. Negative coefficients were found for every water and sewer infrastructure variable: water and sewer grants plus loans, water grants and loans, sewer grants and loans, all grants, and all loans.

The POP coefficient estimate in equation (1) was in the range of 0.40 to 0.50 (Appendix A). This signifies that for every increase of 1,000 in population, the supply for employment will increase by 400 to 500 . This estimate corresponds closely to the labor force participation rate of $51.7 \%$ in West Virginia which is the lowest in the U.S. (average participation rate is 65.6\%) (Weiler 1997). In equation (3), the POP coefficient estimate ranged from 6 to 12. This result indicated that for every increase of 1,000 in county population, county GDP would increase between $\$ 6,000$ and $\$ 12,000$.

The GDP coefficient estimate had the smallest range of any coefficient, between 0.02 and 0.026 . This result means that a $\$ 1$ million increase in county GDP would increase employment demand anywhere from 20 to 26 jobs. The coefficient estimate for VALUE had a wide range of 0.8 to 1.26. These coefficient results mean that a $\$ 1$ million increase in the assessed value of private capital was associated with an approximately $\$ 1$ million increase in county GDP. This relationship between GDP and private capital was higher than previous research findings of 0.33 by Munnell (1990) and 0.30 by Holtz-Eakin (1994).

The WAGE coefficient estimate in equation (1) ranged from -0.2 to -0.4 , but was concentrated between -0.2 and -0.25 . This coefficient means that for every $\$ 1,000$ increase in average wage rates, the supply of labor available for 
employment decreased from 200 to 250 . Munnell (1990) also found that wage rates had a negative impact on employment growth.

The HWY coefficient estimate was significantly different from zero in 1980 at 0.12 and 1994 at 0.07 . This coefficient indicates that in 1980 and 1994, a one-mile increase in highway mileage in a county in associated with an increase in the demand for county level employment of 120 to 70 jobs. This relationship between employment demand and highway construction was approximately 2.5 times larger than a similar relationship found in Wisconsin (Place and Wade 1986).

As noted in Table 4, all coefficient estimates for water and sewer infrastructure variables were negative in equation (3). The statistically significant impacts on GDP from water and sewer infrastructure were in the following ranges: from -286 to $-3,166$ for all loans and grants; from -284 to -312 for sewer loans and grants; -374 for water loans and grants; -749 to 2,919 for loans; and -1849 for grants. These coefficient estimates indicate that a $\$ 1$ increase in per capita water and/or sewer infrastructure decreased county GDP by anywhere from $\$ 280,000$ to $\$ 3$ million depending on if the infrastructure was water or sewer and whether it was a loan or a grant.

\section{DISCUSSION}

\section{RELATIONSHIP BETWEEN ECONOMIC DEVELOPMENT AND INFRASTRUCTURE}

The first objective of this study was to estimate the relationship that exists between economic development and water, sewer, and highway infrastructure. A negative relationship between county GDP and water and sewer infrastructure was consistently found throughout the 
various models examined in this study. However, a positive relationship was found between job growth and highway construction.

The highway variable had a positive, statistically significant relationship with county level employment demand in 1980 and 1994. These positive impacts were both preceded by a rapid expansion in the number of highway miles around the state during the previous 10 -year period ( 210 miles prior to 1980 and 621 miles prior to 1994). During the 10-year periods prior to 1985 and 1990, there were much smaller increases in highway miles (60 and 39 miles, respectively). The results of this research affirm the possibility that highway development can serve as an economic development tool for expanding job growth. The positive, statistically significant coefficients for only 1980 and 1994 provide supporting evidence that highway infrastructure development stimulates job growth over a relatively short period of time (about 10 years).

The coefficients for water and sewer infrastructure were always negative with statistical significance occurring primarily during 1980, 1990 and 1994. It is difficult to explain why this negative relationship exists. How can building new or improving existing water and sewer system infrastructure have a negative impact on county level economic activity? Three possible explanations are presented: 1) a county's ability to attract industry and support economic development; 2) federal and/or state mandated infrastructure development; and 3) the spatial accuracy of the estimated models.

West Virginia is ranked last in economic competitiveness when compared with surrounding states. This finding suggests that the state of West Virginia may be dominated by "lagging" economic regions. As Fox and Smith (1990) noted, lagging economic regions are not positioned for 
economic development because they lack many necessary development ingredients. Regions can lag due to declining economies, unskilled labor forces, and/or inadequate raw materials. Infrastructure in lagging regions tends not to be a limiting factor to economic development.

If numerous West Virginia counties can be considered lagging regions, this could explain both the positive impacts of highways and the negative impacts of water and sewer systems. Highway construction may alleviate a limiting factor to job growth (i.e. transportation) in lagging regions in West Virginia. Conversely, an investment in either new or improved water and/or sewer systems may not generate enough economic activity and thus revenue to pay for the loans and/or operating expenses of the system. This type of infrastructure investment creates further financial difficulties for the lagging regions that could result in a negative relationship between GDP growth and water and sewer infrastructure.

A second possible explanation for this negative relationship is mandated infrastructure investment to meet environmental improvement objectives. This explanation relies on the observation that a substantial portion of infrastructure investments between 1964 and 1994 were required to improve or replace water and/or sewer infrastructure to meet regulatory standards stemming from federal legislation such as the Clean Water Act and the Safe Drinking Water Act. The West Virginia Division of Environmental Protection has estimated that over $\$ 1$ billion has been spent to construct wastewater treatment systems in West Virginia. This represents a major economic investment in this infrastructure category in West Virginia, not to mention an improvement in the quality of the receiving streams in these communities (West Virginia Division of Environmental Protection undated). Thus, infrastructure investments between 1964 and 1994 in West Virginia may 
have been motivated by the need to improve water quality and access to clean water and not by the need to stimulate employment or economic activity.

Kelejian and Robinson (1997) provided the third explanation for the negative impact of infrastructure on economic development. They argue that the regional models used to relate infrastructure to economic productivity have been oversimplified. This explanation focuses mainly on the fact that the spatial effects of infrastructure on economic development have not been taken into consideration in previous research. Spatial effects result from an examination of areas which are either too large or too small relative to the infrastructure. Too large an area includes additional communities which are not impacted by infrastructure while too small an area excludes areas impacted by infrastructure.

In this study, data were aggregated by county for water and sewer infrastructure. County areas may be too large for an appropriate analysis because many communities are included which are not impacted by infrastructure changes. This possibility suggests that the relationship between infrastructure and economic development may be more appropriately studied at the municipal level to properly account for the extent of spatial effects. The twin region approach as employed by Rephann and Isserman (1994) could be utilized in such an analysis.

\section{FINANCIAL ASSISTANCE FOR INFRASTRUCTURE}

The second objective of this study was to examine how different types of financial assistance in water and sewer infrastructure affect a region's economic development. Two types of financial assistance were analyzed: loans and grants. Throughout this study, water and sewer loan coefficients were negative and statistically significant more often than the water and sewer grant coefficients. The grant coefficients 
were significant only in 1980, while the loan coefficients were significant in 1980, 1990 and 1994.

What do these results mean? First, loan financing had a larger negative impact on county GDP than grant financing. This implies that the construction of new or improved water and/or sewer infrastructure with loan assistance will have a more visible impact on a county's GDP than infrastructure obtained through grant assistance. One possible explanation for the negative impact of loans is West Virginia's low economic competitiveness (Dilger and Witt 1994). Because of low economic competitiveness, factors other than infrastructure may be limiting economic growth in the local economies of West Virginia counties.

Infrastructure investment, perhaps in response to regulatory mandates, by itself would not lead to economic growth, rather the loan repayment requirements drain revenues from these local economies. This hinders the counties' economic growth and results in a negative relationship between the loan infrastructure variable and county GDP.

\section{POLICY IMPLICATIONS}

A consistently negative relationship between economic development and water and sewer infrastructure prompts the question of whether infrastructure should be used as an economic development tool. Investment in water and sewer infrastructure between 1964 and 1994 did not produce the economic growth that one might expect. However, infrastructure investments were promoted as an economic development tool in the campaign to approve $\$ 300$ million infrastructure bonds (Seiler 1994). Investments in water and sewer infrastructure were viewed as a means of stimulating the economies of the rural, low-income counties in West Virginia.

As Dilger and Witt (1994) noted, there are a number of 
factors that affect a local economy's response to infrastructure. As historical data from West Virginia indicate, water and sewer infrastructure, by themselves, were not sufficient to promote county economic growth. Thus, infrastructure investment by itself cannot be regarded as an adequate economic development tool. Water and sewer infrastructure, however, must be part of an overall development strategy to attract and retain businesses and other institutions, which generate economic activity. Therefore, the use of infrastructure as a tool in an integrated economic development strategy should not be discounted based upon the results of this study.

The infrastructure investments, which occurred in West Virginia between 1964 and 1994, have led to improvements in water quality (WV Division of Environmental Protection undated). The negative relationship found in this study might represent a trade-off between environmental improvement in water quality and economic activity. The improved environment has the potential for long-term positive effects, such as quality of life improvements which are not necessarily reflected in current county GDP measures. The future economic benefits of water and sewer infrastructure may eventually outweigh the costs, but these benefits, for the most part, remain difficult to quantify. 


\section{REFERENCES}

Appalachian Regional Commission. 1997. 1996 Annual Report. Washington, DC.

Boarnet, Marlon G. 1997. "Highways and Economic Productivity: Interpreting Recent Evidence." Journal of Planning Literature (May): 476-486.

Childs, Randy. 1998. Business Research Analyst, Bureau of Business and Economic Research, College of Business and Economics. West Virginia University, Morgantown, WV.

Conrad, Klaus, and Helmut Seitz. 1994. "The Economic Benefit of Public Infrastructure." Applied Economics 26(4): 303-311.

Council for Community and Economic Development. 1994. "Mountains of Opportunity." West Virginia Development Office, Charleston, WV.

Cox, P. Thomas, C. Wilford Grover, and Bernard Siskin. 1971. "Effect of Water Resource Investment on Economic Growth." Water Resource Research (1): 32-38.

Dilger, Robert J., and Tom S. Witt. 1994. "The $\$ 300$ Million Infrastructure Improvement Amendment." The West Virginia Public Affairs Reporter 11(4): 2-11.

Duffy-Deno, Kevin T., and Randall W. Eberts. 1989. "Public Infrastructure and Regional Development: A Simultaneous Equations Approach." Federal Reserve Bank of Cleveland. Working Paper 8909. 
Fox, William F., and Tim. R. Smith. 1990. "Public Infrastructure Policy and Economic Development. Economic Review 75: 49-59.

Gujarati, Damodar N. 1995. Basic Econometrics, Third Edition. New York, NY: McGraw-Hill, Inc.

Holtz-Eakin, Douglas. 1994. "Public-Sector Capital and the Productivity Puzzle." The Review of Economics and Statistics 76(1): 12-21.

Howe, Charles W. 1968. "Water Resources and Regional Economic Growth in the United States, 1950-1960." Water and Regional Economic Growth (April): 477 489.

Hulten, Charles R., and Robert M. Schwab. 1991. "Public Capital Formation and the Growth of Regional Manufacturing Industries." National Tax Journal 44(4): 121-133.

Judge, George G., R. Carter Hill, William Griffiths, Helmut Lutkepohl, Tsoung-Chao Lee. 1982. Introduction to the Theory and Practice of Econometrics. New York: John Wiley and Sons.

Kelejian, Harry H., and Dennis P. Robinson. 1997. "Infrastructure Productivity Estimation and Its Underlying Econometric Specifications: A Sensitivity Analysis." Papers in Regional Science 76(1): 115-131.

Lewis, John, Jr. 1998. Personal interview. West Virginia Department of Transportation, Department of Highways. Charleston, WV. 
Libbey, Marie, ed. 1995. West Virginia Statistical Abstract, First Edition. Morgantown, WV: Bureau of Business Research, College of Business and Economics, West Virginia University.

Moomaw, Ronald, John K. Mullen, and Martin Williams. 1995. "The Interregional Impact of Infrastructure Capital." Southern Economic Journal 61(3): 830-45.

Munnell, Alicia H. 1990. "How Does Public Infrastructure Affect Regional Economic Performance?” New England Economic Review (September/October):1132.

Place, Frank, and Randall Wade. 1986. "The Relationship of State and Local Government Spending and Taxing to Economic Performance: an Econometric Analysis of the States from 1972 to 1984." Wisconsin Department of Development, Division of Policy Development, Bureau of Research. Madison, WI.

Rephann, Terance, and Andrew Isserman. 1994. "New Highways as Economic Development Tools: An Evaluation Using Quasi-Experimental Matching Methods." Regional Science and Urban Economics 24(6): 723-751.

Rogers, Cynthia, Kimberly Mencken, and F. Carson Mencken. 1997. "Female Labor Force Participation in Central Appalachia: A Descriptive Analysis." Journal of Appalachian Studies 3(2): 189-210.

Seiler, Fanny. 1994. "80-20 Water-Sewer Amendment Split Can Be Changed, Boley Says.” Charleston Gazette. October 9 edition, page B1. 
Weiler, Stephen. 1997. "The Economics of the Struggling Structurally Unemployed." Journal of Appalachian Studies 3(1): 71-97.

West Virginia Department of Transportation, Division of Highways. 1992. "Transportation Needs Study Appalachian Corridor H: Elkins, West Virginia, to Interstate 81, Virginia." Charleston, WV.

West Virginia Division of Environmental Protection.

Undated. "West Virginia Water Quality Status Assessment, 1989-1991.” 305(b) Report. Charleston, WV. 


\section{APPENDIX A}

COEFFICIENT EsTIMATIONS WEIGHTED, TWOSTAGE-LEAST-SQUARES USING STACKED DATA

Table A1. Stacked Regression of Systems Analysis with Water and Sewer Loans and Grants (Stacked Model A)

\begin{tabular}{|c|c|c|c|}
\hline & SUPPLY & DEMAND & GDP \\
\hline Variable & \multicolumn{2}{|c|}{$\begin{array}{l}\text { Coefficient estimates } \\
\text { (Standard error) }\end{array}$} & \\
\hline \multicolumn{4}{|l|}{1980} \\
\hline INTERCEPT & $\begin{array}{l}-0.032821 \\
(0.211258)\end{array}$ & $\begin{array}{l}-0.196193 * \\
(0.042931)\end{array}$ & $\begin{array}{l}9.693679 \\
(11.26590)\end{array}$ \\
\hline POP & $\begin{array}{l}0.469002^{*} \\
(0.013300)\end{array}$ & & $\begin{array}{l}11.37996 \% \\
(2.401095)\end{array}$ \\
\hline WAGE & $\begin{array}{l}-0.196193 * \\
(0.042931)\end{array}$ & $\begin{array}{l}-0.048371 \\
(0.037185)\end{array}$ & \\
\hline GDP & & $\begin{array}{l}0.021048^{*} \\
(0.001104)\end{array}$ & \\
\hline HWY & & $\begin{array}{l}0.119326 * * \\
(0.054132)\end{array}$ & $\begin{array}{l}-2.241575 \\
(2.817169)\end{array}$ \\
\hline VALUE & & & $\begin{array}{l}0.918153^{*} \\
(0.167363)\end{array}$ \\
\hline \multirow[t]{2}{*}{ SWLG } & & & $\begin{array}{l}-3,166.338^{*} \\
(1,001.138)\end{array}$ \\
\hline & \multicolumn{3}{|c|}{ Determinant residual covariance $58,214.05$} \\
\hline $\mathrm{R}^{2}$ & 0.964072 & 0.970136 & 0.977204 \\
\hline
\end{tabular}


Table A1 Continued.

\begin{tabular}{lll}
\hline & SUPPLY DEMAND & GDP \\
\hline Variable & $\begin{array}{l}\text { Coefficient estimates } \\
\text { (Standard error) }\end{array}$ \\
\hline
\end{tabular}

\begin{tabular}{|c|c|c|c|}
\hline \multicolumn{4}{|l|}{1985} \\
\hline \multirow[t]{2}{*}{ INTERCEPT } & 0.057131 & -0.487590 & -28.89711 \\
\hline & $(0.292430)$ & $(0.296364)$ & $(15.32618)$ \\
\hline \multirow[t]{2}{*}{ POP } & $0.448327^{*}$ & & -0.360908 \\
\hline & $(0.013431)$ & & $(5.796899)$ \\
\hline \multirow[t]{2}{*}{ WAGE } & $-0.211993 *$ & 0.057986 & \\
\hline & $(0.061180)$ & $(0.061112)$ & \\
\hline \multirow[t]{2}{*}{ GDP } & & $0.024173^{*}$ & \\
\hline & & $(0.015850)$ & \\
\hline \multirow[t]{2}{*}{ HWY } & & 0.079463 & 2.453063 \\
\hline & & $(0.061275)$ & $(2.534218)$ \\
\hline \multirow[t]{2}{*}{ VALUE } & & & $1.246423^{*}$ \\
\hline & & & $(0.453366)$ \\
\hline \multirow[t]{3}{*}{ SWLG } & & & 223.9540 \\
\hline & & & $(454.6061)$ \\
\hline & \multicolumn{3}{|c|}{ Determinant residual covariance $9,535.778$} \\
\hline $\mathrm{R}^{2}$ & 0.968011 & 0.975774 & 0.957235 \\
\hline
\end{tabular}


Table A1 Continued.

\begin{tabular}{|c|c|c|c|}
\hline & SUPPLY & DEMAND & GDP \\
\hline Variable & \multicolumn{3}{|c|}{ Coefficient estimates } \\
\hline & \multicolumn{3}{|c|}{ (Standard error) } \\
\hline \multicolumn{4}{|l|}{1990} \\
\hline \multirow[t]{2}{*}{ INTERCEPT } & 0.592011 & 0.021917 & $-10.17025^{* * *}$ \\
\hline & $(0.345859)$ & $(0.178579)$ & $(4.610277)$ \\
\hline \multirow[t]{2}{*}{ POP } & $0.50804 *$ & & $5.998117^{* * * *}$ \\
\hline & $(0.019543)$ & & $(2.755440)$ \\
\hline \multirow[t]{2}{*}{ WAGE } & $-0.35089 *$ & -0.030745 & \\
\hline & $(0.070405)$ & $(0.034459)$ & \\
\hline \multirow[t]{2}{*}{ GDP } & & $0.025067^{*}$ & \\
\hline & & $(0.000806)$ & \\
\hline \multirow[t]{2}{*}{ HWY } & & 0.020666 & 0.513654 \\
\hline & & $(0.031659)$ & $(1.269083)$ \\
\hline \multirow[t]{2}{*}{ VALUE } & & & $0.838997^{*}$ \\
\hline & & & $(0.168895)$ \\
\hline \multirow[t]{3}{*}{ SWLG } & & & $-286.8378 *$ \\
\hline & & & $(59.60688)$ \\
\hline & \multicolumn{3}{|c|}{ Determinant residual covariance $6,826.632$} \\
\hline $\mathrm{R}^{2}$ & 0.952959 & 0.989269 & 0.986501 \\
\hline
\end{tabular}


Table A.1 Continued.

\begin{tabular}{|c|c|c|c|}
\hline & SUPPLY & DEMAND & GDP \\
\hline Variable & \multirow{2}{*}{\multicolumn{3}{|c|}{$\begin{array}{l}\text { Coefficient estimates } \\
\text { (Standard error) }\end{array}$}} \\
\hline & & & \\
\hline \multicolumn{4}{|l|}{1994} \\
\hline \multirow[t]{2}{*}{ INTERCEPT } & -0.115109 & 0.141730 & $-11.05298^{* * *}$ \\
\hline & $(0.186329)$ & $(0.102224)$ & $(5.512781)$ \\
\hline \multirow[t]{2}{*}{ POP } & $0.566046^{*}$ & & 11.53837 \\
\hline & $(0.014057)$ & & $(7.182582)$ \\
\hline \multirow[t]{2}{*}{ WAGE } & $-0.283811^{*}$ & $-0.101057 *$ & \\
\hline & $(0.042903)$ & $(0.031600)$ & \\
\hline \multirow[t]{2}{*}{ GDP } & & $0.025580 *$ & \\
\hline & & $(0.000368)$ & \\
\hline \multirow[t]{2}{*}{ HWY } & & $0.069199^{*}$ & -0.097385 \\
\hline & & $(0.021175)$ & $(1.212172)$ \\
\hline \multirow[t]{2}{*}{ VALUE } & & & 0.375714 \\
\hline & & & $(0.285411)$ \\
\hline \multirow[t]{3}{*}{ SWLG } & & & $-323.8206 \%$ \\
\hline & & & $(65.25396)$ \\
\hline & \multicolumn{3}{|c|}{ Determinant residual covariance $3,536.752$} \\
\hline $\mathrm{R}^{2}$ & 0.965899 & 0.991781 & 0.980148 \\
\hline
\end{tabular}


Table A2. Stacked Regression of Systems Analysis with Water Loans and Grants and Sewer Loans and Grants (Stacked Model B)

\begin{tabular}{|c|c|c|c|}
\hline & SUPPLY & DEMAND & GDP \\
\hline Variable & \multirow{2}{*}{\multicolumn{3}{|c|}{$\begin{array}{l}\text { Coefficient estimates } \\
\text { (Standard error) }\end{array}$}} \\
\hline & & & \\
\hline \multicolumn{4}{|l|}{1980} \\
\hline \multirow[t]{2}{*}{ INTERCEPT } & -0.048269 & -4.703957 & 13.44883 \\
\hline & $(0.206890)$ & $(0.187826)$ & $(16.40709)$ \\
\hline \multirow[t]{2}{*}{ POP } & $0.467789 *$ & & $12.73217^{*}$ \\
\hline & $(0.012860)$ & & $(3.776917)$ \\
\hline \multirow[t]{2}{*}{ WAGE } & $-0.191309 *$ & -0.043610 & \\
\hline & $(0.040670)$ & $(0.035176)$ & \\
\hline \multirow[t]{2}{*}{ GDP } & & $0.020964 *$ & \\
\hline & & $(0.001084)$ & \\
\hline \multirow[t]{2}{*}{ HWY } & & $0.120679 * *$ & -2.873261 \\
\hline & & $(0.054119)$ & $(3.968947)$ \\
\hline \multirow[t]{2}{*}{ VALUE } & & & $0.844963 *$ \\
\hline & & & $(0.249812)$ \\
\hline \multirow[t]{2}{*}{ W } & & & $-2,556.704$ \\
\hline & & & $(1,388.587)$ \\
\hline \multirow[t]{2}{*}{$S$} & & & $-6,272.447$ \\
\hline & & & $(3,717.005)$ \\
\hline
\end{tabular}

Determinant residual covariance $110,519.0$

\begin{tabular}{cccc}
\hline $\mathrm{R}^{2}$ & 0.963982 & 0.970028 & 0.958074 \\
\hline $\begin{array}{l}\text { shows statistical significance at } \\
\text { shows statistical significance at }\end{array}$, two-sided \\
swo-sided
\end{tabular}


Table A2 Continued.

\begin{tabular}{|c|c|c|c|}
\hline & SUPPLY & DEMAND & GDP \\
\hline Variable & \multirow{2}{*}{\multicolumn{2}{|c|}{$\begin{array}{l}\text { Coefficient estimates } \\
\text { (Standard error) }\end{array}$}} & \\
\hline & & & \\
\hline \multicolumn{4}{|l|}{1985} \\
\hline \multirow[t]{2}{*}{ INTERCEPT } & 0.038258 & -0.373033 & -56.99671 \\
\hline & $(0.275883)$ & $(0.237111)$ & $(67.77451)$ \\
\hline \multirow[t]{2}{*}{ POP } & $0.447778^{*}$ & & -7.930804 \\
\hline & $(0.013123)$ & & $(20.75224)$ \\
\hline \multirow[t]{2}{*}{ WAGE } & $-0.207563^{*}$ & 0.032232 & \\
\hline & $(0.056806)$ & $(0.047604)$ & \\
\hline \multirow[t]{2}{*}{ GDP } & & $0.02476 *$ & \\
\hline & & $(0.001282)$ & \\
\hline \multirow[t]{2}{*}{ HWY } & & 0.058605 & 5.442172 \\
\hline & & $(0.050521)$ & $(7.20587)$ \\
\hline \multirow[t]{2}{*}{ VALUE } & & & 1.768057 \\
\hline & & & $(1.507893)$ \\
\hline \multirow[t]{2}{*}{ W } & & & $2,178.619$ \\
\hline & & & $(3,815.283)$ \\
\hline \multirow[t]{3}{*}{ S } & & & 181.5869 \\
\hline & & & $(797.6804)$ \\
\hline & \multicolumn{3}{|c|}{ Determinant residual covariance $35,857.24$} \\
\hline $\mathrm{R}^{2}$ & 0.968078 & 0.980211 & 0.851412 \\
\hline $\begin{array}{l}\text { shor } \\
\text { shor }\end{array}$ & $\begin{array}{l}\text { istical sign } \\
\text { istical sign }\end{array}$ & $\begin{array}{l}\text { cee at } 10 \% \text {, } \\
\text { tce at } 5 \% \text {, }\end{array}$ & $\begin{array}{l}\text {-sided } \\
\text { ided }\end{array}$ \\
\hline
\end{tabular}


Table A2 Continued.

\begin{tabular}{|c|c|c|c|}
\hline & SUPPLY & DEMAND & GDP \\
\hline Variable & \multicolumn{2}{|c|}{$\begin{array}{l}\text { Coefficient estimates } \\
\text { (Standard error) }\end{array}$} & \\
\hline \multicolumn{4}{|l|}{1990} \\
\hline INTERCEPT & $\begin{array}{l}0.592516 \\
(0.345706)\end{array}$ & $\begin{array}{l}0.024254 \\
(0.176562)\end{array}$ & $\begin{array}{l}-10.85099 * * \\
(5.336017)\end{array}$ \\
\hline POP & $\begin{array}{l}0.50796 * \\
(0.019445)\end{array}$ & & $\begin{array}{l}5.961538^{* * *} \\
(2.81752)\end{array}$ \\
\hline WAGE & $\begin{array}{l}-0.350861 * \\
(0.070416)\end{array}$ & $\begin{array}{l}-0.031137 \\
(0.034162)\end{array}$ & \\
\hline GDP & & $\begin{array}{l}0.02508^{*} \\
(0.000792)\end{array}$ & \\
\hline HWY & & $\begin{array}{l}0.01985 \\
(0.03028)\end{array}$ & $\begin{array}{l}0.646074 \\
(1.461381)\end{array}$ \\
\hline VALUE & & & $\begin{array}{l}0.841063^{*} \\
(0.172316)\end{array}$ \\
\hline W & & & $\begin{array}{l}-236.8055 \\
(188.551)\end{array}$ \\
\hline \multirow[t]{2}{*}{ S } & & & $\begin{array}{l}-312.6503^{*} \\
(92.63911)\end{array}$ \\
\hline & \multicolumn{3}{|c|}{ Determinant residual covariance $7,128.649$} \\
\hline $\mathrm{R}^{2}$ & 0.952938 & 0.989277 & 0.986169 \\
\hline
\end{tabular}


Table A2 Continued.

\begin{tabular}{|c|c|c|c|}
\hline & SUPPLY & DEMAND & GDP \\
\hline Variable & \multirow{2}{*}{\multicolumn{3}{|c|}{$\begin{array}{l}\text { Coefficient estimates } \\
\text { (Standard error) }\end{array}$}} \\
\hline & & & \\
\hline \multicolumn{4}{|l|}{1994} \\
\hline \multirow[t]{2}{*}{ INTERCEPT } & -0.147896 & 0.159345 & -10.02372 \\
\hline & $(0.17814)$ & $(0.095471)$ & $(5.873204)$ \\
\hline \multirow[t]{2}{*}{ POP } & $0.563057^{*}$ & & 10.55105 \\
\hline & $(0.013147)$ & & $(7.659689)$ \\
\hline \multirow[t]{2}{*}{ WAGE } & $-0.272243 *$ & $-0.108015^{*}$ & \\
\hline & $(0.038349)$ & $(0.027899)$ & \\
\hline \multirow[t]{2}{*}{ GDP } & . & $0.025595^{*}$ & \\
\hline & & $(0.000388)$ & \\
\hline \multirow[t]{2}{*}{ HWY } & & $0.072131 *$ & 0.112722 \\
\hline & & $(0.020357)$ & $(1.333452)$ \\
\hline \multirow[t]{2}{*}{ VALUE } & & & 0.411992 \\
\hline & & & $(0.300608)$ \\
\hline S & & & $\left(-374.3061^{*}\right)$ \\
\hline \multirow[t]{3}{*}{ W } & & & $-284.8391^{* * *}$ \\
\hline & & & (121.9699) \\
\hline & \multicolumn{3}{|c|}{ Determinant residual covariance $3,211.575$} \\
\hline $\mathrm{R}^{2}$ & 0.965920 & 0.991626 & 0.981867 \\
\hline $\begin{array}{l}\text { sho } \\
\text { shor }\end{array}$ & $\begin{array}{l}\text { stical signi } \\
\text { stical signi }\end{array}$ & $\begin{array}{l}\text { ce at } 10 \%, t \\
\text { ce at } 5 \%, t h\end{array}$ & $\begin{array}{l}\text {-sided } \\
\text { sided }\end{array}$ \\
\hline
\end{tabular}


Table A3. Stacked Regression of Systems Analysis with Water and Sewer Loans and Water and Sewer Grants (Stacked Model C)

\begin{tabular}{|c|c|c|c|}
\hline & SUPPLY & DEMAND & GDP \\
\hline Variable & \multicolumn{3}{|c|}{ Coefficient estimates } \\
\hline & \multicolumn{3}{|c|}{ (Standard error) } \\
\hline \multicolumn{4}{|l|}{1980} \\
\hline \multirow[t]{2}{*}{ INTERCEPT } & 0.009457 & -0.215313 & 9.657634 \\
\hline & $(0.21129)$ & $(0.190819)$ & $(10.58507)$ \\
\hline \multirow[t]{2}{*}{ POP } & $0.471354^{*}$ & & $10.4427^{*}$ \\
\hline & $(0.013246)$ & & $(2.095089)$ \\
\hline \multirow[t]{2}{*}{ WAGE } & $-0.207958 *$ & -0.055135 & \\
\hline & $(0.042862)$ & $(0.036857)$ & \\
\hline \multirow[t]{2}{*}{ GDP } & & $0.021179 *$ & \\
\hline & & $(0.001092)$ & \\
\hline \multirow[t]{2}{*}{ HWY } & & $0.115521^{* *}$ & -1.388512 \\
\hline & & $(0.053742)$ & $(2.518211)$ \\
\hline \multirow[t]{2}{*}{ VALUE } & & & $0.931586^{*}$ \\
\hline & & & $(0.158585)$ \\
\hline \multirow[t]{2}{*}{$\mathrm{L}$} & & & $-2,919.774^{*}$ \\
\hline & & & $(899.0815)$ \\
\hline \multirow[t]{3}{*}{ G } & & & $-1,849.32 * * *$ \\
\hline & & & $(788.4764)$ \\
\hline & \multicolumn{3}{|c|}{ Determinant residual covariance $46,640.72$} \\
\hline $\mathrm{R}^{2}$ & 0.964149 & 0.970385 & 0.978827 \\
\hline sho & $\begin{array}{l}\text { tical signi } \\
\text { tical signi }\end{array}$ & $\begin{array}{l}\text { cee at } 10 \% \text {, t } \\
\text { ace at } 5 \% \text {, tw }\end{array}$ & $\begin{array}{l}\text {-sided } \\
\text { sided }\end{array}$ \\
\hline
\end{tabular}


Table A3 Continued.

\begin{tabular}{|c|c|c|c|}
\hline & SUPPLY & DEMAND & GDP \\
\hline Variable & \multicolumn{3}{|c|}{ Coefficient estimates (standard error) } \\
\hline \multicolumn{4}{|l|}{1985} \\
\hline \multirow[t]{2}{*}{ INTERCEPT } & 0.030054 & -0.488401 & -29.79794 \\
\hline & $(0.293417)$ & $(0.298113)$ & $(18.28874)$ \\
\hline \multirow[t]{2}{*}{ POP } & $0.448537^{*}$ & & -0.503166 \\
\hline & $(0.013381)$ & & $(6.839405)$ \\
\hline \multirow[t]{2}{*}{ WAGE } & $-0.20726^{*}$ & 0.058263 & \\
\hline & $(0.061399)$ & $(0.06141)$ & \\
\hline \multirow[t]{2}{*}{ GDP } & & $0.024173^{*}$ & \\
\hline & & $(0.001573)$ & \\
\hline \multirow[t]{2}{*}{ HWY } & & 0.079148 & 2.528979 \\
\hline & & $(0.060938)$ & $(2.620512)$ \\
\hline \multirow[t]{2}{*}{ VALUE } & & & $1.256667 * *$ \\
\hline & & & $(0.528884)$ \\
\hline \multirow[t]{2}{*}{$\mathrm{L}$} & & & 172.0032 \\
\hline & & & $(1,064.593)$ \\
\hline \multirow[t]{3}{*}{ G } & & & 264.555 \\
\hline & & & $(483.9272)$ \\
\hline & \multicolumn{3}{|c|}{ Determinant residual covariance $9,807.848$} \\
\hline $\mathrm{R}^{2}$ & 0.968132 & 0.975754 & 0.955363 \\
\hline $\begin{array}{l}\text { shows } \\
\text { shows }\end{array}$ & $\begin{array}{l}\text { istical signif } \\
\text { istical signif }\end{array}$ & $\begin{array}{l}\text { ce at } 10 \%, \mathrm{t} \\
\text { ce at } 5 \%, \mathrm{tw}\end{array}$ & $\begin{array}{l}\text { sided } \\
\text { ided }\end{array}$ \\
\hline
\end{tabular}


Table A3 Continued.

\begin{tabular}{|c|c|c|c|}
\hline & SUPPLY & DEMAND & GDP \\
\hline Variable & \multicolumn{2}{|c|}{$\begin{array}{l}\text { Coefficient estimates } \\
\text { (standard error) }\end{array}$} & \\
\hline \multicolumn{4}{|l|}{1990} \\
\hline INTERCEPT & $\begin{array}{l}0.847336 \\
(0.438491)\end{array}$ & $\begin{array}{l}0.062525 \\
(0.203076)\end{array}$ & $\begin{array}{l}-9.281984^{* * *} \\
(4.618274)\end{array}$ \\
\hline POP & $\begin{array}{l}0.510025 * \\
(0.021925)\end{array}$ & & $\begin{array}{l}6.508246^{*} \\
(2.711485)\end{array}$ \\
\hline WAGE & $\begin{array}{l}-0.404473 * \\
(0.088168)\end{array}$ & $\begin{array}{l}-0.039917 \\
(0.38868)\end{array}$ & \\
\hline GDP & & $\begin{array}{l}0.025234 * \\
(0.000783)\end{array}$ & \\
\hline HWY & & $\begin{array}{l}0.014585 \\
(0.031497)\end{array}$ & $\begin{array}{l}0.586783 \\
(1.2197)\end{array}$ \\
\hline VALUE & & & $\begin{array}{l}0.800976 * \\
(0.167483)\end{array}$ \\
\hline $\mathrm{L}$ & & & $\begin{array}{l}-758.7971^{*} \\
(226.9859)\end{array}$ \\
\hline \multirow[t]{2}{*}{ G } & & & $\begin{array}{l}18.64914 \\
(149.5118)\end{array}$ \\
\hline & \multicolumn{3}{|c|}{ Determinant residual covariance $8,903.668$} \\
\hline $\mathrm{R}^{2}$ & 0.940055 & 0.989306 & 0.987633 \\
\hline
\end{tabular}


Table A3 Continued.

\begin{tabular}{|c|c|c|c|}
\hline & SUPPLY & DEMAND & GDP \\
\hline Variable & $\begin{array}{l}\text { Coefficient } \\
\text { (standard er }\end{array}$ & & \\
\hline
\end{tabular}

1994

$\begin{array}{llll}\text { INTERCEPT } & -0.11487 & 0.129033 & -9.847716 \\ & (0.181181) & (0.096471) & (5.110131) \\ \text { POP } & 0.563084^{*} & & 10.95862 \\ & (0.013412) & & (6.847287)\end{array}$

WAGE $\quad-0.278927^{*} \quad-0.095458^{*}$

$(0.040161) \quad(0.028498)$

GDP

$0.02557^{*}$

$(0.000383)$

HWY

$\begin{array}{ll}0.066518^{* *} & 0.175488 \\ (0.02015) & (1.129824)\end{array}$

VALUE

0.397395

(0.271642)

L

$-749.0944^{*}$

(279.1273)

G

$-54.72538$

(111.9536)

Determinant residual covariance $3,399.539$

\begin{tabular}{llll}
\hline $\mathrm{R}^{2}$ & 0.966143 & 0.991876 & 0.982523 \\
\hline$* * *$ & $\begin{array}{l}\text { shows statistical significance at } \\
\text { shows statistical significance at } 5 \%, \text { two-sided }\end{array}$ \\
$*$ two-sided
\end{tabular}


Notes 
NoTES 


\section{NOTES}


West Virginia University is an Equal

Opportunity/Affirmative Action Institution. The

University does not discriminate on the basis of race, sex, age, handicap, veteran status, religion, sexual orientation, color, or national origin in the administration of any of its educational programs, activities, or with respect to admission or employment. The University neither affiliates knowingly with nor grants recognition to any individual, group, or organization having policies that discriminate on the basis of race, sex, age, handicap, veteran status, religion, sexual orientation, color, or national origin, as defined by the applicable law and regulations. Further, faculty, staff, students, and applicants are protected from retaliation for filing complaints or assisting in an investigation under the University's Equal Opportunity Policy/Affirmative Action Plan. Inquiries regarding the University's nondiscrimination policy may be directed to the Director of Affirmative Action Office/Equal Employment Opportunity Program, West Virginia University. -- OFFICE OF THE PRESIDENT

\section{UNIVERSITY SYSTEM OF WEST VIRGINIA BOARD OF} TRUSTEES: Charles W. Manning, Chancellor; David G. Todd, Chairman; Cathy M. Armstrong, Vice Chairman; Ron D. Stollings, Secretary; Richard M. Adams, Derek H. Anderson, Phyllis H. Arnold, Sophia B. Blaydes, John R. Hobitzell, Lucia B. James, J. Thomas Jones, Sharon B. Lord, Paul R. Martinelli, A. Michael Perry, Joseph W. Powell, Bruce M. Van Wyk, Henry R. Marockie, ExOfficio; Clifford M. Trump, Ex-Officio.

\section{WEST VIRGINIA UNIVERSITY BOARD OF ADVISORS:} Irene Keeley, Chair; Thomas A. Winner, Vice Chair; Vaughn Kiger, Secretary; Richard Beto, Dennis M. Bone, John W. Fisher III, Kay Goodwin, Adam S. Green, Sharon A. Nicol, James M. Shumway, Jr., David C. Hardesty, Jr., President, West Virginia University; Kathryn A. Brailer, President, Potomac State College; Eldon Miller, President, WVU-Parkersburg; John Carrier, President, WVU Institute of Technology. 
West Virginia University

West Virginia Agricultural and Forestry Experiment Station College of Agriculture, Forestry and Consumer Sciences

1170 Agricultural Sciences Bldg. PO Box 6108

Morgantown, WV 26506-6108
Non-Profit Organization U.S. Postage PAID

Morgantown, WV

Permit No. 34 